\title{
Research Paper: Brain Death According to the Sunni Jurisprudence
}

\author{
Mahmood Abbasi ${ }^{1}$ (D), Jahandar Amini' ${ }^{1}$ (D), Nazli Mahmoodian ${ }^{1}$ (i) \\ 1. Medical Ethics and Law Research Center, Shahid Beheshti University of Medical Sciences, Tehran, Iran.
}

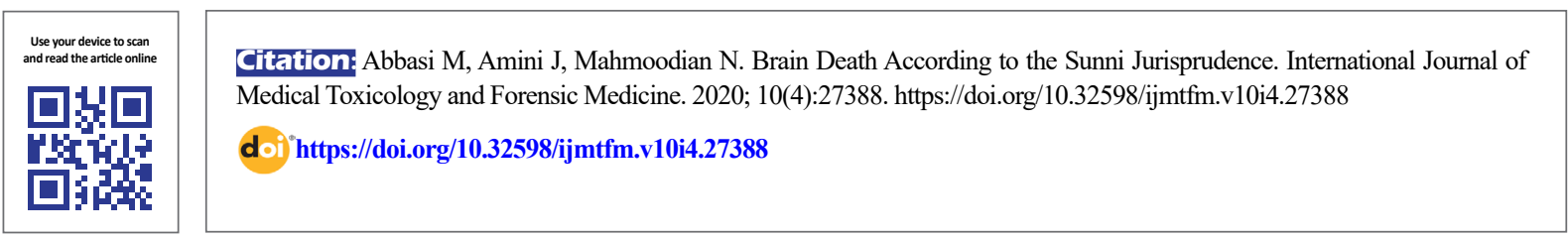

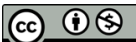

Article info:

Received: 08 Oct 2019

First Revision: 30 Oct 2019

Accepted: 04 Nov 2019

Published: 06 Dec 2020

\section{Keywords:}

Brain death, Real death, Physicians, Jurisprudence, Holy Quran

\section{A B STRACT}

Background: Brain death is a new medical term that appeared in the second half of the $20^{\text {th }}$ century. Some research about it has already conducted in law, but no academic research in this field from the Sunni jurisprudents point of view.

Methods: Because this is a theoretical study in theology, our primary research method is library research.

Results: There are different opinions about brain death in Sunni jurisprudence, which can be divided into three groups of supporters, opponents, and neutrals. Some jurisprudents do not recognize brain death due to their respect for the human soul. According to principles such as asceticism and the observance of the custom of the universe, the death of patients with brain death is not certain, and subsequently, it is not allowed to separate assist devices from the patient and the perception of their members. However, the second group, considering the lack of human life and according to the theory of medical commission, which is the same convention, brain death is considered to be a definite death, so it is allowed to separate the assist devices from the patient and the withdrawal of its members. The neutrals consider brain death as one of the examples of definitive death, but for some jurisprudential rulings, legal rights are not considered in the death sentence.

Conclusion: The brain death is the complete cessation of the activities of the brain, including the brain stem and cortex. By diagnosis and announcing the brain death, the patient is considered as a dead body regardless of lungs and heart function even with the help of a resuscitator. It seems the reasons of the supporters of brain death are favorable. So the resuscitator should be separated from the patient with brain death.

\section{Introduction}

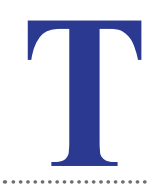

he exact time of death because of its jurisprudence, legal, and medical consequences for an organ transplant from a dead body to alive one is crucial. But, when can a person be considered dead? Todays, resuscitators have changed the time of death in incurable diseases. So, the timing of human death for turning off resuscitators because of civil and panel liability based on the jurisprudence and law is essential.

* Corresponding Author:

Mahmood Abbasi, PhD.

Address: Medical Ethics and Law Research Center, Shahid Beheshti University of Medical Sciences, Tehran, Iran

Tel: +98 (912) 1183249

E-mail:drabbasi@sbmu.ac.ir 
By the advancement of medical science at the end of the 20th century, the question of what is real death appeared. Physicians believe that the cessation of the brain function as the leader of the body and not responding to signals is real death, regardless of the heart and lungs' proper function [1]. But it is different from the conventional idea of real death because most people believe that stopping of the heart beating and breathing is the actual death. According to the religion, separation of the soul from the body is real death.

In this study, we tried to answer these questions: 'Whether brain death is a real death? According to the Islamic religion, what the Islamic Jurisprudents' opinions are about the brain death? And whether a brain death patient is alive or dead?'

\section{Materials and Methods}

Because this is a theoretical study in theology, the primary research method is library research. The essential information was collected by using Jurisprudences and legal books and papers. After that, the information was thoroughly studied and revised.

\section{Library research}

The term "death" means losing a life [2], and anybody who loses his or her life is considered dead [3].

\section{Real death, according to the Holy Quran}

Different types of death have been mentioned in the Holy Quran [4], such as definite death when the death is inevitable; suspended death, when the occurrence of death is conditioned; optional death, when optionally giving up on deeds, properties, and void thoughts; and ambiguous death [5].

I. To give life by it to a thirsty and dry land (Surah AlFurqan, verse 49).

II. Is he the one who was dead, and we give him life (Surah Al-Anam, verse 122).

III. Allah is the one who takes the souls of men at the time of their death, and while they are sleeping (Surah Zumar, verse 42).

The separation of the soul from the body is the meaning that all Islamic Jurisprudents accept as the meaning of death, and the Holy Quran confirms it [6]. Besides, the Holy Quran has talked about some aspects of death (like life after death) that contemporary medical knowledge does not have a clear and exact explanation for that. The truth of death, like the truth of life, is one of the existence's secrets, in a way that its truth has not become evident for anybody, and what we know about it is only its effects. What is clear about it, is that our Holy Book, the Quran, is very inclusive and exact about death [5].

\section{Physicians' point of view about brain death}

Physicians believe that cessation of breathing, circulation, and nervous system for some minutes, and after that, body consumption and its deformation is real death. Also, the irreversible stop of the activities of all parts of the brain, such as the brainstem, is called brain death [7], even when some organs of the body are still working. To be assured of brain death, first, there should be a clear reason for irreparable damage to the brain, like shooting a bullet to skull, and second, all activities of the brain should be stopped that includes the cortex and brainstem activities [8] (Figure 1).

An unconscious patient without automatic breathing, eye reaction to the light, and body movement is considered as a brain dead one.

Loss of thinking and memory after a concussion is called coma (not brain death) that can be continued for some months or years. In this situation, the brainstem is alive, and the body has its automatic breathing and heart activity. So, it is not called real death [9].

For biologic reasons, physicians believe death happens in three stages: first, the clinical death in which the lungs and heart activities stop; second, the brain death which occurs after inadequate oxygen and blood reach

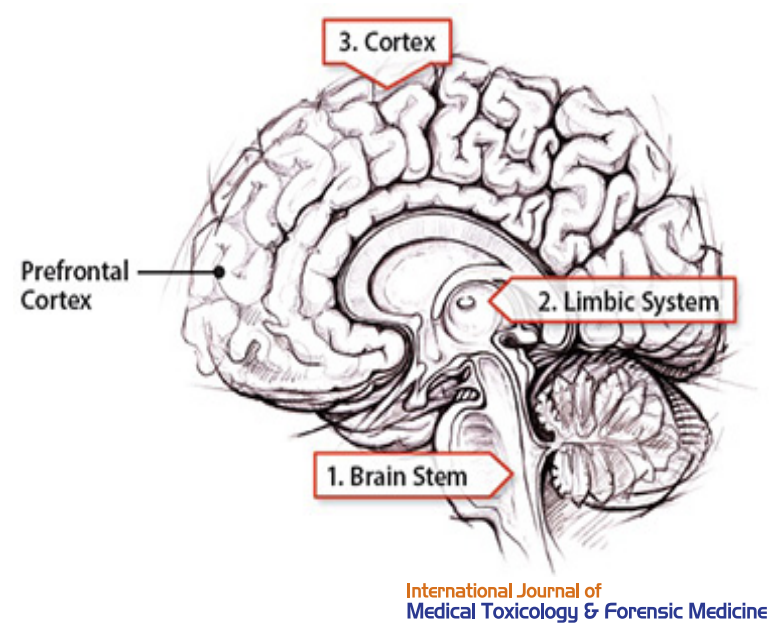

Figure 1. Active parts of the brain 
to the brain for 4 or 6 minutes; and third, the cell death in which the cells necrosis happens [10].

Nowadays, most physicians consider brain death as the real death, and they believe it happens because of oxygen and blood missing to the brain vessels and cessation of the nervous system's activities regardless of the lungs and heart's function [11].

\section{Religion's point of view about Brain death}

According to Sunni jurisprudents, death is the separation of the soul from the body. But what is the nature of the soul? According to this verse of the Holy Quran: "And they ask you concerning man's soul. Say: "Knowledge about the soul is only with my Creator and Nurturer, and of this knowledge, you have been given only a little." (Surah Al-Isra, verse 85]

Nobody can answer this question [12]. But others think the soul is some shiny and light thing like water in plant or fire in coal [13]. So, the soul is an immortal entity in the human body until death. Also, the human cannot describe it because the soul is runic, and human is limited to place and time [14].

According to an anecdote of our holy prophet Mohammad (PBUH), the soul enters to the fetus' body in its 4-month old [15] and also he declared some signs for soul leaving the body and especially death, for example, cessation of heart beating and breathing, body codding and non-movement, and languishing of vessels [16].

But these signs appear progressively, so determining the exact time of soul leaving the body is impossible. Therefore, reliance on these signs for starting the transplant procedure is wrong. Thus, nowadays, the physicians try to find the exact time of the soul leaving the body for organ transplant [17].

The complete cessation of brain activities is the real time of the soul leaving of the body because the activities of other parts of the body depend on the brain, and the death of the brain is followed by the progressive death of other organs [18].

As a result, based on the religion's viewpoint, the separation of the soul from the body is the separation of the soul from the brain, and the brain death can be considered as the real death.
Jurisprudents point of view about the brain death

Brain death as a real death has not been accepted by all physicians and jurisprudents. There are several opinions about it, which are divided into three groups: supporters, opponents, and neutrals.

\section{Supports of "brain death" as a real death}

Some of the Islamic scientific centers, such as the Islamic Jurisprudence Center in Jeddah, Saudi Arabia, Medical Islamic Institution, and some Islamic Jurisprudence scholarly believe that the brain death is the real death, regardless of the lungs and heart function (Table 1). Their reasons are:

First, the existence of the soul in the body is subject to its flaunting in the body that has volitional movement. If the body is incapable of voluntary movements that happen after brain death, this time is the exact time of soul leaving the body and, in other words, the real death [19].

Second, jurisprudents believe that if a person hurts somebody, then another one causes his or her death by other damages. However, the second one causes his or her death, but the first one is a murderer because the infirmed life is like death. Therefore when the soul is in the body with its regular and voluntary movement, it is alive [20]. This consideration proves the theory the time of real death is associated with the body's immobility [21], which is the result of brain death.

Third, anybody who loses his or her intelligence is like a dead one, and it undoubtedly happens in brain death [22].

Fourth, the Jurisprudents believe that when newborn cries, he or she is alive, and other signs like sneezing or urinating are not a reason for living, and crying is one of the brain's activities. If the newborn does not cry, it shows his or her death, that it happens in brain death, too [23].

Fifth, most scientific centers believe that the death of the brainstem and cortex is real death. Some Jurisprudents consider this subject and agree with scientific centers' opinions [24].

\section{Opponents of "brain death" as a real death}

Some of the Islamic scientific centers, such as the Islamic Jurisprudence Center in Jeddah, Saudi Arabia, Medical Islamic Institution, and some Islamic Jurisprudence scholarly believe that the brain death is the real death, regardless of the lungs and heart function (Table 1). Their reasons are: 
Some of the Islamic religious institutions, for example, the Islamic Conference Center, Egyptian Daralefta, and some Islamic Jurisprudence researchers and scholars declare that brain death without heart activities stopping is not real death (Table 1). They have some reasons for their opinion [25]:

First of all, according to 11 and 12 verses of Kahf Surah in the Holy Quran, losing consciousness cannot be the sign of real death even for a long time [26].

Second, based on religious principles, death is the end of life and happens when the soul leaves the body; therefore, death is the moment of stopping all activities of all parts of the body [14]. Thus, because in brain death the activities of some parts of the body do not stop, the brain death cannot be real death.

Third, jurisprudents believe that if there is doubt about somebody's death, waiting for conviction is necessary [27]. Heart beating after the brain death is a sign of doubtful death; therefore, any time the heart is beating, it is not real death [28].

Forth, in brain death, heart and lungs working even with the resuscitator. This condition is the sign of life, so, brain death is not real death [14].

Fifth, sometimes, the brain activities stop because of using narcotics, breathing some poison gases, or hormonal disruption. These conditions are curable. So, cessation of the brain activates because of brain death does not mean real death [26].

Sixth, the outcome of brain death is the absence of awareness, so it cannot be real death because unconsciousness and witless are causes and do not mean death [29].

Seventh, according to the jurisprudence principle, the doubt cannot annihilate the conviction. So because of the heart beating, the uncertainty of death cannot annihilate the conviction of life [13].
Eighth, according to the jurisprudence principles, because the person was alive before brain death, he or she was alive after brain death [30].

\section{Neutrals}

This group believes that brain death, in some aspects, is real death, but in some other aspects, is not:

First, jurisprudents believe that if a person hurts somebody, then another one causes his or her death by other damages. However, the second one causes his or her death, but the first one is a murderer because the infirmed life is like death. Therefore any time the soul is in the body with its normal and voluntary movement, the person is alive [31]. Brain death is similar to that, and separating resuscitators from the patient is not killing him or her. But the subject of his or her inheritance is exceptional [21].

Second, the human body sees different kinds of life, such as cell life, fetus life, firm life, and infirm life although there are different kinds of death: the death of all parts of the body, and the death of some parts of the body [32].

\section{Results}

There are different opinions about brain death in Sunni jurisprudence, which are divided into three groups of supporters, opponents, and neutrals. Some jurisprudents do not recognize brain death as the real death due to respect for the human soul, and according to principles such as asceticism and the observance of the custom of the universe. They believe that these patients do not bound to die. Subsequently, they do not allow the separation of assist devices from the patient and the perception of their members. However, the second group, considering the lack of human life and according to the theory of medical commission, which is the same as a convention, consider the brain death as a definite death, and it is permissible to separate the assist devices from the patient and the withdrawal of its members. Finally, others

Table 1. Different opinions about brain death in Sunni jurisprudence

\begin{tabular}{cc}
\hline \multicolumn{1}{c}{ Opinions } & Supporters \\
\hline $\begin{array}{c}\text { Supporters of “brain death" as real death } \\
\text { Opponents of "brain death" as real death }\end{array}$ & Islamic Jurisprudence Center in Jeddah, Medical Islamic Institution, and some of \\
Islamic Jurisprudence scholarly
\end{tabular}


consider brain death as one of the examples of definitive death, but for some jurisprudential rulings, legal rights are not considered in the death sentence. Considering the reasons developed by all groups, it seems that the ideas of the first group, the group that believes brain death is real death, is more favorable.

Moreover, any time the head is separated from the body, the heart beating will continue for 20 minutes, and the blood circulation does not stop. In some countries, brain death is accepted as real death, and the heart transplant is done when the heart beats without any resuscitator for 20 minutes [33].

The brain death undoubtedly is real death regardless of the heart beating. According to physicians, when a body without the head is connected to a resuscitator, its breathing and heart beating will continue. So, it seems the heart and other organs can continue to function without the soul because some organs can be alive even out of the body by resuscitator. Also, when a heart is being frozen for a long time, and then, after melting, it regains its beating, nobody says it is alive and has a soul. As a result, we can say that in real death, not all the activities of organs and tissue of the body need to stop at the same time, but it happens gradually [34].

In addition, the fetus is nourishing and grows, and its heart starts beating in the fourth week, even though the soul has not entered the fetus. Also, the Holy Quran declares:

"Then we made the sperm into a clot then we made the clot a lump of flash then we turned the lump into bones then we dressed the bones with flesh then by enjoying soul into the body we made a complete creation: the source of blessing is Allah, the only creator." (Surah AlMu'minun, verse 14).

\section{According to the religious principle that declares}

The strong opinions in any subject are the opinions of its specialists. As the brain death at real is a medical subject, so the physician's opinions are preferable than jurisprudents' views about it. So, if the physicians accept brain death as real death, the jurisprudents should accept it, too. In this regard, the physician's purpose for using resuscitator for brain death patients is not curing, but for intensive care of their organs for grafting.

The medical science advancement and invention of new resuscitators provides more information about the body and more ways for curing. Although some years ago, the stop of heart beating and breathing were the signal of death, nowadays, by using resuscitators, these organs can continue their functions, and the death of the brainstem is called real death because the death of brainstem causes the death of other organs gradually.

There is no cure for brain stem death nowadays, but there may be some cure for it in the future, so if something like this happens at that time, we cannot consider the brain death as a real death.

\section{Conclusion}

The Sunni Jurisprudents have three different ideas about brain death, but the idea of the group which believes the brain death is the real death according to what the medical science says is the acceptable idea. As a result, brain death is real death, according to the Islamic religious view. By diagnosis and announcing the brain death, the patient is considered dead regardless of lungs and heart function even with the help of a resuscitator. So, the resuscitator can be separated from the patient with brain death.

\section{Ethical Considerations}

\section{Compliance with ethical guidelines}

All ethical principles were considered in this article.

\section{Funding}

This research did not receive any specific grant from funding agencies in the public, commercial, or not-profit sectors.

\section{Author's contributions}

All authors contributed in preparing this artilce.

\section{Conflict of interest}

The authors declared no conflict of interest.

\section{References}

[1] Al-Daqr NMN. [The death of the brain between medicine and Islam (Arabic)]. Damascus: House of Thought;. 1997. http:/ / opac.nlai.ir/opac-prod/search/briefListSearch do? command=FULL_VIEW\&id=929199\&pageStatus $=0 \&$ so rtKeyValue1=sortkey_title\&sortKeyValue2=sortkey_author

[2] Ebenmazour JM. [Arabes tong. $1^{\text {st }}$ Edition (Arabic)] Beirut: Sader Publishing House; 1956. http://opac.nlai.ir/ 
opac-prod/search/briefListSearch.do?command=FULL_VI EW\&id $=891539 \&$ pageStatus $=0 \&$ sortKeyValue1 $=$ sortkey title\&sortKeyValue2=sortkey_author

[3] Anis I. Abdel-Halim M, Attia S, Mohamed A. [The medial glossary was overseen by Hassan Attia, Mohamed Amin. $2^{\text {nd }}$ Edition. Beirut: Heritage Revival House (Arabic)]. Beirut: Heritage Revival House; 2004. http://opac.nlai.ir/ opac-prod/search/briefListSearch.do?command=FULL_VI EW\&id $=896699 \&$ pageStatus $=0 \&$ sortKeyValue1= sortkey title\&sortKeyValue2=sortkey_author

[4] Al-Omar A. [Brain death. Riyadh $1^{\text {st }}$ Edition (Arabic)]. Riyadh: The Arab Academy for Security Sciences; 2006. https:/ / core.ac.uk/download/pdf/80743315.pdf

[5] Najari F, Mostafazadeh B, Najari F, Baradaran I. Different types of death from the viewpoint of quran and forensic medicine. nternational Journal of Medical Toxicology and Forensic Medicine. 2016; 6(4):225-30. http://journals.sbmu.ac.ir/ ijmtfm/article/view/11188

[6] Ghotb S. [At the shade of holy (Arabic)]. Quran. Beirut: Dar Alsharoogh: 1978. http://opac.nlai.ir/opac-prod/ search/briefListSearch.do?command=FULL_VIEW\& $\mathrm{id}=572748 \&$ pageStatus $=0 \&$ sortKeyValue $1=$ sortkey title\&sortKeyValue2=sortkey_author

[7] Rouhani M, Noghani F. [Medical jurisprudence (Persian)]. Tehran: Tabib Publisher; 1999. https://www.gisoom.com/ book/

[8] Abbasi M. [Organs transplantation (Persian)]. Tehran: Hoghoghi Publishing; 2009. http://opac.nlai.ir/opac-prod/bibliographic/1894920

[9] Goodarzi. F. Forensic medicine. Tehran: Einstein; 1998. https://www.gisoom.com/book/11

[10] Sharfaoddin, A. [The legal provisions of medical practice $2^{\text {nd }}$ Edition (Arabic)]. Kuwait: National Council for Culture, Arts and Letters; 1987. http://opac.nlai.ir/opacprod/search/briefListSearch.do?command=FULL_VIE W\&id=916638\&pageStatus $=0 \&$ sortKeyValue1 $=$ sortkey_ title\&sortKeyValue2=sortkey_author

[11] Soleyman M. Egypt. Annals of The International Geophysical Year. 1959; 9:81-3. [DOI:10.1016/B978-1-4832-13101.50024-2]

[12] Al-Jundi IS. [Brain death $1^{\text {st }}$ edition (Arabic)]. Riyadh: The Arab Academy for Security Sciences; 2001. p. 25. https:/ /library.nauss.edu.sa/cgi-bin/koha/opac-detail. pl?biblionumber $=2851 \&$ query_desc $=\mathrm{kw} \% 2 \mathrm{Cwrdl} \% 3 \mathrm{~A} \% 20$

[13] Al-Zahabi M. Organs transplantation in medical \& religion (Arabic)]. Egypt: Dar-al-Hadis; 1993. https:// www.neelwafurat.com/itempage.aspx?id=egb990975098785\&search=books

[14] Al-Shanqati MM. [The provisions of medical surgery and their implications (Arabic)]. Jeddah: Library of the Companions; 1994. https:/ / www.waqfeya.com/book.php?bid=618

[15] Ebne-al-ghayyem MA. [The Soul (Arabic)]. Beirut: Scientific Arabic Book House; 1975. http://opac.nlai.ir/opacprod/search/briefListSearch.do?command=FULL_VIE W\&id $=1263649 \&$ pageStatus $=0 \&$ sortKeyValue1 $=$ sortkey title\&sortKeyValue2=sortkey_author
[16] Al-Bokari MA. [Sahih Al-bokari (Arabic)]. Egypt: Almaktab Alsharafiyyeh; 1978. http://opac.nlai.ir/opac-prod/ search/briefListSearch.do?command=FULL VIEW\&id $=307$ 9439\&pageStatus $=2 \&$ sortKeyValue1 $=\&$ sortKeyValue2 $=$

[17] Al-Noovi YNS. [Menhaj Al Talebin (Arabic)]. Beirut; Dar Albashaer Al-Islamiye; 2000. http://opac.nlai.ir/opacprod/search/briefListSearch.do?command=FULL_VIE W\&id $=932176 \&$ pageStatus $=0 \&$ sortKeyValue1 $=$ sortkey title\&sortKeyValue2=sortkey_author

[18] Abbasi M. [The articles on medical law (Persian)]. Tehran: Hayyan Institution; 1997. http://opac.nlai.ir/opacprod/search/briefListSearch.do?command=FULL_VIE W\&id $=542791 \&$ pageStatus $=0 \&$ sortKeyValue $1=$ sortkey_ title\&sortKeyValue2=sortkey_author

[19] Sharfaoddin A. The legal provisions of medical practice. Egypt: Faculty of Law Ain Shams University. [Arabic] $2^{\text {nd }}$ edition. 1987; 174. http://opac.nlai.ir/opac-prod/ search / briefListSearch.do?command=FULL_VIEW\& id $=3922847 \&$ pageStatus $=0$ \& sortKeyValue1= sortkey title\&sortKeyValue2=sortkey_author

[20] Al-Shanqati MM. The provisions of medical surgery and their implications. Jeddah: Library of the Companions. $2^{\text {nd }}$ edition. 1994; 30. https://www.waqfeya.com/book. php?bid $=618$

[21] Ebn-e-Ghodameh MA. Al-Moghni \& it's extended description. Beirut; Arabic Book Center. 1981; 384. http:/ / opac.nlai. ir/opac-prod/search/briefListSearch.do?command=FULL VIEW\&id=3922847\&pageStatus $=0 \&$ sortKeyValue $1=$ sortk ey_title\&sortKeyValue2=sortkey_author

[22] Aldosooghi M. [Marginal of dosooghi for extended description (Arabic)]. Beirut; Dar Al-fekr; 1996. http:/ / opac.nlai ir/opac-prod/search/briefListSearch.do?command=FULL VIEW\&id $=1157324 \&$ pageStatus $=0$ \&sortKeyValue $1=$ sortk ey_title\&sortKeyValue2=sortkey_author

[23] Sharfaoddin A. The legal provisions of medical practice. Egypt: Faculty of Law Ain Shams University. [Arabic]. $2^{\text {nd }}$ edition. 1987; 174. http://opac.nlai.ir/opac-prod/ search/briefListSearch.do? command=FULL_VIEW\& $\mathrm{id}=916638 \&$ pageStatus $=0 \&$ sortKey Value1=sortkey_ title\&sortKeyValue2=sortkey_author.

[24] Al-Salami ShM. [When is the life entire (Arabic)]. Kuwait: University of Kuwait; 1983. p. 425. https:// shamela.ws

[25] Melibary HM. [The definition of death at the point view of medical and religion (Arabic)]. Kuwait: University of Kuwait; 1994. p. 671. https://shamela.ws

[26] Al-Nadi MI. [Death of the brain and the position of Islamic jurisprudence (comparative study) (Arabic)]. Egypt: Law Center; 2016. https:/ / www.neelwafurat.com/itempage. aspx?id=egb149700-5160562\&search=books

[27] Sheikh KhA. [Medical issues and contemporary financial transactions, section ii. of the course of the scientific course (Arabic)]. Riyadh: Mosque of Al-Rajhi; 2003. https://shamela.ws

[28] Ebn-e-Rooshd MA. [Bedayat almojtahid \& nehayat almoghtased (Arabic)]. Beirut: Knowledge Center; 1984 http:/ / opac.nlai.ir/opac-prod/search/briefListSearch do? command=FULL_VIEW\&id=3314868 $\&$ pageStatus $=0 \&$ so rtKeyValue1=sortkey_title\&sortKeyValue2=sortkey_author 
[29] Al-Bar MA. [Brain death (Arabic)]. Journal of Islamic Jurisprudence Center. No date; 3:550. https:/ / shamela.ws

[30] Al-Vae T. [Death \& life at holy Quran and Religion (Arabic)]. Kuwait: University of Kuwait; 1983. https:/ /al-maktaba.org/book/8356/1483

[31] Al-Mutairi A. [Brain death and its shariah adaptation comparative juristic jurisprudence study (Arabic)] [Internet]. 2006 [Updated 2018 July 26]. Available from: https://b2n. ir/489662

[32] Ashqar S. [The legal center of the brain. Jordan (Arabic)]. Kuwait: Nashiri House for Electronic Publishing; 2004. https://www.goodreads.com/book/show/12333457

[33] Al-Bar MA. [The difference of clinical death and religion death (Arabic)] [Internet]. 2010 [Updated 2001 January 09] Available from: https://alhadyalzahry.yoo7.com/t1065topic

[34] Shahin F. [Definition of death (Arabic)]. Kuwait: University of Kuwait; 1994. p. 294. http://ecat.kfnl.gov.sa:88/ipac20/ ipac.jsp?session=1G9274Q510F88.8253\&profile=akfnl\&uri=li nk=3100023@ 